UDC 548.736:546.561

\author{
A.I. Yanchak ${ }^{a}$, Yu.I. Slyvka ${ }^{a}$, V.V. Kinzhybalo ${ }^{b}$, T.J. Bednarchuk ${ }^{b}$, M.G. Mys'kiv ${ }^{a}$
}

\title{
THE FIRST COPPER(I) HALIDE $\pi$-COMPLEXES WITH ALLYL DERIVATIVES OF UREA AND PARABANIC ACID
}

\author{
a Ivan Franko National University of Lviv, Lviv, Ukraine \\ b Institute of Low Temperature and Structure Research, Wroclaw, Poland
}

\begin{abstract}
By means of alternating current electrochemical synthesis with wire copper electrodes in methanolic solutions of corresponding ligands and copper(II) halide salts, two novel copper(I) $\pi$-complexes $\left[\mathrm{Cu}_{2}(\mathrm{dau}) \mathrm{Cl}_{1.58} \mathrm{Br}_{0.42}\right]$ (I) and $\left[\mathrm{Cu}_{2}(\right.$ dapa $\left.) \mathrm{Cl}_{1.74} \mathrm{Br}_{0.26}\right]$ (II) (where dau and dapa are 1,3-diallylurea and 1,3-diallylparabanate, respectively) were prepared in well-shaped crystalline form and studied with X-ray diffraction method. Compound I crystallizes in orthorhombic crystal system, space group $\mathrm{P} 2_{1} 2_{1} 2_{1}: a=8.047$ (3) $\AA, b=8.154(3) \AA$, $\mathrm{c}=16.533(5) \AA, \mathrm{V}=1085.8(76) \AA^{3}, \mathrm{Z}=4$. Compound II crystalizes in monoclinic crystal system, space group I2/a: $a=6.420(3) \AA, b=8.088(3) \AA, c=49.020(9) \AA, \beta=90.92(3)^{0}$, $\mathrm{V}=2545.03(16) \AA^{3}, Z=8$. Both structures contain two crystallographically independent copper(I) ions with one half in trigonal planar coordination environment and the other half in trigonal pyramidal one. Both compounds are built of parallel copper halide polymeric chains of one type in I and two types in II, cross-linked by organic ligand molecules to produce 3D-polymer bulk in I and 2D-layered structure in II. In compound I, 1,3diallylurea is both $\pi$ - and $\sigma$-bonded to copper(I) halide chains (by means of two allylic $\mathrm{C}=\mathrm{C}$ bonds and carbonyl $\mathrm{O}$ atom), whereas 1,3 -diallylparabanate is a solely $\pi$-donor ligand in compound II. The structure of II is noteworthy due to the combination of two different chain types that have been previously observed only separately in copper(I) halide coordination compounds.
\end{abstract}

Keywords: copper(I) halides, $\pi$-complex, diallylurea, diallylparabanate, crystal structure.

DOI: $10.32434 / 0321-4095-2019-124-3-67-73$

\section{Introduction}

Copper(I) halides are known to form diverse structures in combination with organic ligands [1], including the ones capable of being $\pi$-coordinated, for example described in [2-4].

A large number of olefin-copper(I) $\pi$-complexes is known to date. A common approach toward the design of ligands is combining rigid fragments such as heteroatom-containing molecules ( $\sigma$-donors) with flexible allyl group substituents ( $\pi$-coordination) [5]. Additional hydrogen atoms connected to heteroatoms are involved in hydrogen bonds formation, that further stabilizes the crystal structures.

A good example of such fragment, which possesses both potential $\sigma$-donating oxygen atom as well as groups capable of hydrogen bonds formation is urea. Its 1,3-diallyl derivative (dau) has already been investigated as a ligand for $\pi$-complexation of silver [6] due to the structural similarity to $1,3,5-$ cyanuric acid (Fig. 1) and has demonstrated its ability to be a linker in coordination polymers. Nevertheless, its behavior in presence of compounds that can catenate on their own has never been tested prior to this moment. An example of such partners for dau are copper(I) halides.

Another ligand, structurally related to 1,3diallylurea, is 1,3-diallylparabanate (dapa) (Fig. 1). This compound has been studied in context of useful polymer materials preparation [7]. Nevertheless, its use as a ligand for copper(I) $\pi$-coordination is novel. This ligand has a similar spatial arrangement of allyl groups, as in 1,3-diallylurea, while not being able to donate hydrogen bonds and being more sterically hindered. 1,3-Diallylparabanate possesses only oxygen atoms as potential $\sigma$-donor with their hard basic properties not favorable for bonding with soft acidic $\mathrm{Cu}^{+}$. Consequently, the dapa ligand is a good candidate for solely $\pi$-complexation while possibly 
retaining bridging function.<smiles>C=CCNC(=O)NCC=C</smiles>

a

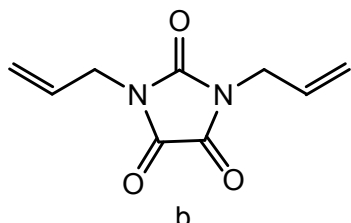

b
Fig. 1. Chemical structures of 1,3-diallylurea (dau) (a) and 1,3-diallylparabanate (dapa) (b)

Inspired by respective earlier studied silver complexes of dau [6], two compounds, $\left[\mathrm{Cu}_{2}(\mathrm{dau}) \mathrm{Cl}_{1.58} \mathrm{Br}_{0.42}\right]$ (I) and $\left[\mathrm{Cu}_{2}(\right.$ dapa $\left.) \mathrm{Cl}_{1.74} \mathrm{Br}_{0.26}\right]$ (II), were prepared and studied by $\mathrm{X}$-ray diffraction in this work.

\section{Experimental}

Synthesis of the ligands

1,3-diallylurea (dau) was prepared starting from the unsubstituted urea and allylamine in a similar approach as described elsewhere [8].

For the synthesis of 1,3-diallylparabanate (dapa), sodium parabanate was prepared starting from urea and diethyloxalate according to the known procedure [9]. The salt was then alkylated in methanol with allyl bromide yielding dapa.

Preparation of $\left[\mathrm{Cu}_{2}(\mathrm{dau}) \mathrm{Cl}_{1.58} \mathrm{Br}_{0.42}\right]$ (I)

To $4 \mathrm{~mL}$ of ethanol solution of $\mathrm{CuCl}_{2} \cdot \mathrm{H}_{2} \mathrm{O}$ $(2.4 \mathrm{mmol}, 0.409 \mathrm{~g}), 0.322 \mathrm{~g}(2.3 \mathrm{mmol})$ of dau and $0.247 \mathrm{~g}(2.4 \mathrm{mmol})$ of $\mathrm{NaBr}$ were added. The mixture was carefully stirred and the resulting solution was placed into a $5 \mathrm{~mL}$ test tube and then copper-wire electrodes in cork were inserted. With the application of an alternating current (voltage of $0.56 \mathrm{~V}$, frequency of $50 \mathrm{~Hz}$ ) for 3 days the good quality colorless crystals of I appeared on the copper electrodes in a very small amount.

\section{Preparation of $\left[\mathrm{Cu}_{2}(\right.$ dapa $\left.) \mathrm{Cl}_{1.74} \mathrm{Br}_{0.26}\right]$ (II)}

To methanol solution $(4 \mathrm{~mL})$ of $\mathrm{CuCl}_{2} \cdot 2 \mathrm{H}_{2} \mathrm{O}$ $(2.4 \mathrm{mmol}, 0.409 \mathrm{~g}), 0.447 \mathrm{~g}(2.3 \mathrm{mmol})$ of dapa and $0.247 \mathrm{~g}(2.4 \mathrm{mmol})$ of $\mathrm{NaBr}$ were added. The mixture, after careful stirring, was subjected to an alternating current (voltage of $0.70 \mathrm{~V}$, frequency of $50 \mathrm{~Hz}$ ) for 4 days. Crystals of II appeared on the copper electrodes. The yield was about $45 \%$. IR (FT-IR Spectrum BX-II (Perkin Elmer), nujol, $\mathrm{cm}^{-1}$ ): $1770(\mathrm{~m}), 1727(\mathrm{~s}), 1656(\mathrm{~m}), 1636(\mathrm{~m}), 1627(\mathrm{~m})$, 1548(m), 1523(w), 1414(m), 1405(m), 1351(m), 1336(m), 1318(m), 1296(w), 1258(w), 1174(vw), 1167(vw), 1140(vw), 1132(vw), 1106(vw), 1076(vw), 1033(vw), 981(vw), 956(vw), 942(w), 925(w), 916(vw), 882(vw), 854(vw), 846(vw), 832(vw), 823(vw), 767(vw), 758(w), 742(vw), 722(w), 677(vw), 649(vw), 578(vw), $553(\mathrm{vw}), 522(\mathrm{w}), 488(\mathrm{w})$, 471(vw), 449(vw), 435(vw).

Single crystal $X$-ray diffraction studies

Diffraction data for I and II crystals were collected on an Oxford Diffraction Xcalibur fourcircle diffractometer with $\operatorname{MoK}_{\alpha}$ radiation $(\lambda=$ $=0.71073 \AA)$ and an Atlas CCD detector. The collected diffraction data were processed with the CrysAlis PRO program. The structures were solved by ShelXT program [13] and refined by least squares method on $\mathrm{F}^{2}$ by ShelXL program [14] with the following graphical user interface of $\mathrm{OLEX}^{2}$ [15]. Atomic displacements for non-hydrogen atoms were refined using an anisotropic model. Chlorine and bromine in both structures statistically occupy the halogen positions (ratios of 0.796(3):0.204(3) \& $0.782(3): 0.218(3)$ in complex $I$ and ratios of $0.860(16): 0.140(16) \& 0.879(15): 0.121(15))$ in complex II). Hydrogen atoms were placed in ideal positions and refined as riding atoms with relative isotropic displacement parameters. The crystallographic parameters and summaries of data collection for I and II are presented in Table 1.

\section{Results and discussion}

1,3-Diallyl urea (dau) in the structure of $\pi$-complex $\left[\mathrm{Cu}_{2}(\mathrm{dau}) \mathrm{Cl}_{1.58} \mathrm{Br}_{0.42}\right]$ (I) serves as a ligand possessing both $\sigma$ - and $\pi$-coordination abilities. Atom $\mathrm{Cu} 1$ in I adopts trigonal pyramidal coordination surrounding $\left(\tau_{4}=0.78\right.$, where $\tau_{4}$ is the geometry index calculated elsewhere [10]) that consists of $\mathrm{C} 7=\mathrm{C} 8$ bond of the allyl group and $\mathrm{O} 1$ atom of the same dau molecule and two halogen ions (Hall \& Hal2) of the endless copper(I) halide polymer chain. $\mathrm{Cu} 1$ deviates from the base plane of coordination polyhedron by $0.28(1) \AA$, whereas the angle between $\mathrm{C} 7=\mathrm{C} 8$ line and the base plane is $9.6(1)^{0}$. Ion $\mathrm{Cu} 2$ in I possesses planar trigonal coordination environment formed by $\mathrm{C} 10=\mathrm{C} 11$ bond of the other allyl group of dau and two halogen ions of the neighboring infinite chain (Fig. 2, Table 2). $\pi, \sigma$-Coordination of the one half of copper ions and $\pi$-coordinated to the other half of copper shows similarity to dau's behavior in silver (I) complexes [6].

Copper halide 1D-polymer chains (Fig. 3) stretch along [010] in the crystal of the complex I. The chains are linked by the bridging molecules of dau into 3D-polymer.

1,3-Diallyl parabanate is exclusively $\pi$-coordinated in the structure of the compound $\left[\mathrm{Cu}_{2}\left(\mathrm{C}_{9} \mathrm{H}_{10} \mathrm{~N}_{2} \mathrm{O}_{3}\right) \mathrm{Cl}_{1.74} \mathrm{Br}_{0.26}\right]$ (II). Ion $\mathrm{Cul}$ forms trigonal pyramidal surrounding $\left(\tau_{4}=0.76\right)$ that consists of Hall, Halli and Hallii ions of the ladder-like copper halide polymer chain and $\mathrm{C} 7=\mathrm{C} 8-$ bond of 
Selected crystal data and structure remement parameters of I and II

\begin{tabular}{|c|c|c|}
\hline Characteristics & $\bar{I}$ & II \\
\hline CCDC number ${ }^{a}$ & 1890065 & 1870895 \\
\hline Empirical formula & $\mathrm{C}_{7} \mathrm{H}_{12} \mathrm{Br}_{0.42} \mathrm{Cl}_{1.58} \mathrm{Cu}_{2} \mathrm{~N}_{2} \mathrm{O}$ & $\mathrm{C}_{9} \mathrm{H}_{10} \mathrm{Br}_{0.26} \mathrm{Cl}_{1.74} \mathrm{Cu}_{2} \mathrm{~N}_{2} \mathrm{O}_{3}$ \\
\hline Formula weight & 356.95 & 403.78 \\
\hline Temperature, $\mathrm{K}$ & 100 & 100 \\
\hline Wavelength & $\mathrm{MoK}_{\alpha}$ & $\mathrm{MoK}_{\alpha}$ \\
\hline Crystal system, space group & Orthorhombic, $\mathrm{P} 2_{1} 2_{1} 2_{1}$ & Monoclinic, I2/a \\
\hline \multirow{3}{*}{$\begin{aligned} \text { Unit cell dimensions: } & \text { a, } \AA \\
& \text { b, } \AA \\
& \text { c, } \AA\end{aligned}$} & $8.047(3)$ & $6.420(3)$ \\
\hline & $8.154(3)$ & $8.088(3)$ \\
\hline & $16.533(5)$ & $49.020(9)$ \\
\hline$\beta,{ }^{0}$ & 90 & $90.92(3)$ \\
\hline $\mathrm{V}, \AA^{3}$ & $1084.8(7)$ & $2545.0(16)$ \\
\hline$\underline{Z}$ & 4 & 8 \\
\hline Calculated density, $\mathrm{g} \mathrm{cm}^{-3}$ & 2.186 & 2.108 \\
\hline Absorption coeff., $\mathrm{mm}^{-1}$ & 5.831 & 4.526 \\
\hline$\overline{F(000)}$ & 702 & 1590 \\
\hline Crystal size, $\mathrm{mm}^{3}$ & $0.32 \times 0.13 \times 0.12$ & $0.15 \times 0.09 \times 0.04$ \\
\hline Color & colorless & colorless \\
\hline Theta range for data collection, ${ }^{0}$ & $2.5-29.6$ & $4.1-28.0$ \\
\hline Measured reflections & 57513 & 1739 \\
\hline Used in refinement & 2945 & 1248 \\
\hline Refined parameters & 130 & 105 \\
\hline $\mathrm{R}\left[\mathrm{F}^{2}>2 \sigma\left(\mathrm{F}^{2}\right)\right], \mathrm{wR}\left(\mathrm{F}^{2}\right), \mathrm{S}$ & $0.0192,0.0407,1.097$ & $0.0805,0.2176,1.005$ \\
\hline
\end{tabular}

Note: ${ }^{a}$ CCDC 1890065 and 1870895 contain the supplementary crystallographic data for this paper. Copies of the data can be obtained free of charge on applications to the Director, CCDC, 12 Union Road, Cambridge CB2 1EZ, UK (Fax: int.code +(1223)336033; e-mail for inquiry: fileserv@ccdc.cam.ac.uk).

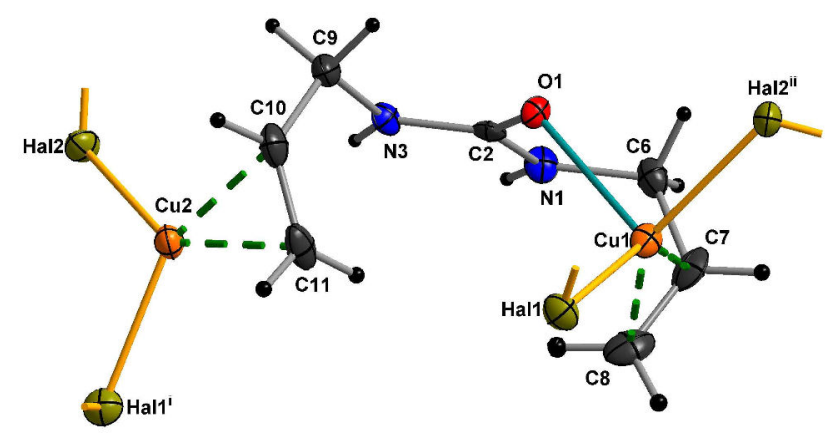

Fig. 2. Numbering scheme in structure of compound I.

Thermal ellipsoids are shown at $70 \%$ probability level.

Symmetry codes: (i) $\mathrm{x}+1 / 2,-\mathrm{y}+1 / 2,-\mathrm{z}+1$; (ii) $-\mathrm{x}+1 / 2$,

$$
-\mathrm{y}+1, \mathrm{z}+1 / 2
$$

the allyl group (Fig. 4, Table 3). Cu1 deviates from the base plane of coordination polyhedron by $0.38(1) \AA$, whereas the angle between $\mathrm{C} 7=\mathrm{C} 8$ line and the base plane is $4.3(1)^{0}$. In contrast to $\mathrm{Cu} 1, \mathrm{Cu} 2$ ion is located in the trigonal surrounding that consists of Hal2 and $\mathrm{Hal}^{\mathrm{iii}}$ ions and $\mathrm{C} 10=\mathrm{C} 11$ bond of the other allyl group of the same dapa molecule. However,

Selected bond distances and angles in the structure of compound I

\begin{tabular}{|c|c|c|c|}
\hline Bond & $\mathrm{d}, \AA$ & Angle & $\omega,^{\circ}$ \\
\hline $\mathrm{Cu} 1-\mathrm{C} 7$ & $2.098(3)$ & Hall-Cu1- $\mathrm{m}_{1}$ & $124.14(9)$ \\
\hline $\mathrm{Cu} 1-\mathrm{C} 8$ & $2.071(3)$ & $\mathrm{O} 1-\mathrm{Cu} 1-\mathrm{m}_{1}$ & $97.17(10)$ \\
\hline $\mathrm{Cu} 1-\mathrm{m}_{1}{ }^{\mathrm{a}}$ & $1.970(3)$ & $\mathrm{Hal}^{\mathrm{ii}}-\mathrm{Cu} 1-\mathrm{m}_{1}$ & $123.64(9)$ \\
\hline $\mathrm{C} 7-\mathrm{C} 8$ & $1.362(5)$ & Hal1-Cu1-Hal2 ${ }^{\mathrm{ii}}$ & $107.42(2)$ \\
\hline Cu1-Hal1 & $2.3017(10)$ & O1-Cu1-Hal2 ${ }^{\mathrm{ii}}$ & $92.23(5)$ \\
\hline Cu1-Hal2 & $2.3753(10)$ & O1-Cu1-Hall & $102.28(5)$ \\
\hline $\mathrm{Cu} 1-\mathrm{O} 1$ & $2.279(2)$ & $\mathrm{Hal} 2-\mathrm{Cu} 2-\mathrm{m}_{2}$ & $126.56(9)$ \\
\hline $\mathrm{Cu} 2-\mathrm{C} 10$ & $2.092(3)$ & $\mathrm{Hall}{ }^{\mathrm{i}}-\mathrm{Cu} 2-\mathrm{m}_{2}$ & $128.76(9)$ \\
\hline $\mathrm{Cu} 2-\mathrm{C} 11$ & $2.060(3)$ & Hal2-Cu2-Hal1 ${ }^{\mathrm{i}}$ & $104.04(2)$ \\
\hline $\mathrm{Cu} 2-\mathrm{m}_{2}^{\mathrm{b}}$ & $1.962(3)$ & Hal1-Cu1-Hal2 ${ }^{\mathrm{ii}}$ & $107.42(2)$ \\
\hline $\mathrm{C} 10-\mathrm{C} 11$ & $1.359(4)$ & $\mathrm{Cu} 1-\mathrm{Hal1}-\mathrm{Cu} 2^{\text {iv }}$ & $90.57(3)$ \\
\hline $\mathrm{Cu} 2-\mathrm{Hal1}^{\mathrm{i}}$ & $2.3086(10)$ & $\mathrm{Cu} 2-\mathrm{Ha} 2-\mathrm{Cu}^{\mathrm{iii}}$ & $117.06(3)$ \\
\hline $\mathrm{Cu} 2-\mathrm{Hal} 2$ & $2.2950(8)$ & & \\
\hline
\end{tabular}

Note: ${ }^{\mathrm{a}} \mathrm{m}_{1}$ is the midpoint of $\mathrm{C} 7=\mathrm{C} 8$ bond; ${ }^{\mathrm{b}} \mathrm{m}_{2}$ is the midpoint of $\mathrm{C} 10=\mathrm{C} 11$ bond. Symmetry codes: (i) $\mathrm{x}+1 / 2,-\mathrm{y}+1 / 2,-\mathrm{z}+1$; (ii) $-\mathrm{x}+1 / 2,-\mathrm{y}+1, \mathrm{z}+1 / 2$; (iii) $-\mathrm{x}+1 / 2,-\mathrm{y}+1, \mathrm{z}-1 / 2$; (iv) $\mathrm{x}-1 / 2,-\mathrm{y}+1 / 2,-\mathrm{z}+1$. Hal stands for statistically present halogen ions: chloride and bromide. 


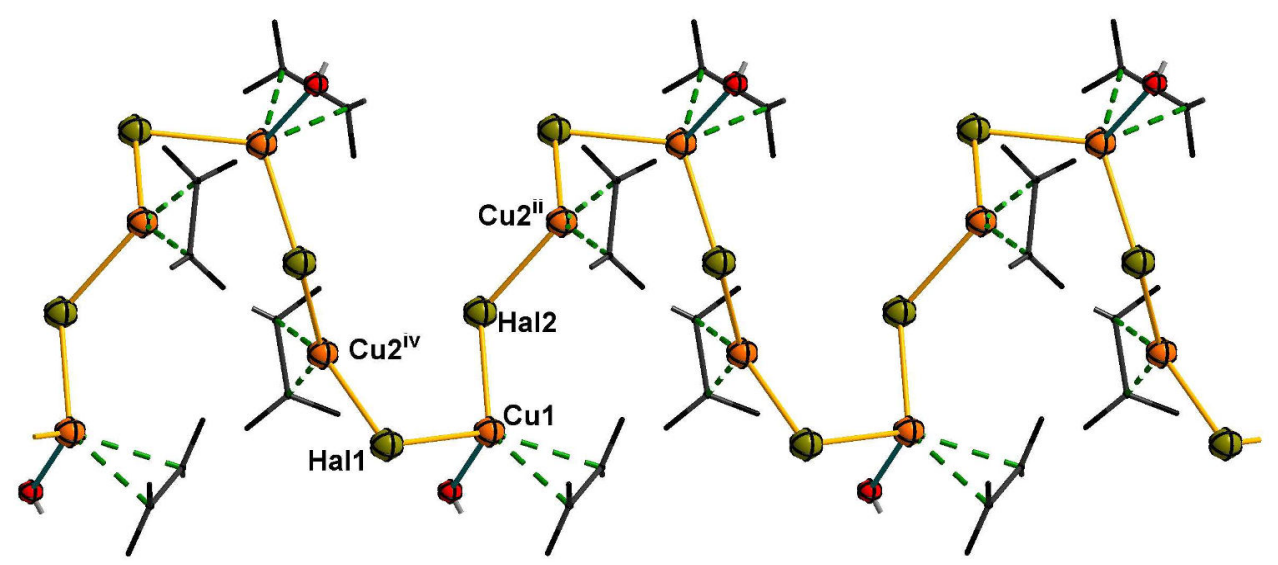

Fig. 3. Fragment of polymer copper(I) halide chain in compound I. Symmetry codes:

(ii) $-\mathrm{x}+1 / 2,-\mathrm{y}+1, \mathrm{z}+1 / 2$; (iv) $\mathrm{x}-1 / 2,-\mathrm{y}+1 / 2,-\mathrm{z}+1$

Table 3 protrusions of the sheet entering the depressions of

Selected bond distances and angles in the structure of compound II

\begin{tabular}{|c|c|c|c|}
\hline Bond & $\mathrm{d}, \AA$ & Angle & $\omega,{ }^{0}$ \\
\hline $1-\mathrm{C} 7$ & $.08(2)$ & alli-Cu1- & 018 \\
\hline & 4 & & \\
\hline$d 1-n$ & $7(2)$ & Hall & $124.2(6)$ \\
\hline$-c$ & $.3 /(3)$ & $\mathrm{Hall}{ }^{\mathrm{ii}}-\mathrm{Cu}$ & 98.50 \\
\hline 11-Hall ${ }^{\mathrm{i}}$ & $2.704(5)$ & Hall ${ }^{\mathrm{ii}}-\mathrm{Cu} 1-$ & $105.06(17)$ \\
\hline & $2.366(5)$ & Hall ${ }^{1}-\mathrm{C}$ & $92.84(14)$ \\
\hline $1^{\mathrm{ii}}$ & $2.364(6)$ & $\mathrm{Ha}$ & $132.3(6)$ \\
\hline & $2.09(2)$ & & (6) \\
\hline & $1.99(2)$ & $\mathrm{Ha}$ & 10 \\
\hline & $1.91(2)$ & & 86.8 \\
\hline & $1.44(3)$ & $\mathrm{Cu} 1-\mathrm{H}$ & $81.70(18)$ \\
\hline C & $2.254(5)$ & $\mathrm{Cu} 1^{\mathrm{i}-\mathrm{Hal1}-\mathrm{C}}$ & $99.40(18)$ \\
\hline u2-Hal2 & $2.291(6)$ & $\mathrm{Cu} 2-\mathrm{Hal} 2-\mathrm{Cu} 2^{\mathrm{iv}}$ & $111.1(2)$ \\
\hline
\end{tabular}

Note: ${ }^{\mathrm{a}} \mathrm{m}_{1}$ is the midpoint of $\mathrm{C} 7=\mathrm{C} 8$ bond; ${ }^{\mathrm{b}} \mathrm{m}_{2}$ is the midpoint of $\mathrm{C} 10=\mathrm{C} 11$ bond. Symmetry codes: (i) $-\mathrm{x}+1 / 2, \mathrm{y},-\mathrm{z}+1$; (ii) $-\mathrm{x}+1, \ll \mathrm{y},-\mathrm{z}+1$; (iii) $\mathrm{x}+1 / 2,-\mathrm{y}+1, \mathrm{z}$; (iv) $\mathrm{x}-1 / 2,-\mathrm{y}+1, \mathrm{z}$. Hal stands for statistically present halogen ions: chloride and bromide.

$\sigma$-coordination is not observed for any oxygen atom in dapa in comparison to oxygen atom in dau, what is in consistence with harder Lewis basicity.

The two types of infinite copper(I) halide polymer chains propagating in parallel direction are cross-linked by the dapa molecules into $2 \mathrm{D}$-sheets and for every a-type double strand chain (Cu1\&Hall) two b-type chains (Cu2\&Hal2) are present (Fig. 5). Similar chain geometries were observed in other copper(I) halide complexes in both a-type [11] (copper(I) iodide) and b-type [12] chains (copper (I) chloride and iodide).

The sheets are stacked on each other with the adjacent sheets and vice versa. $\mathrm{Cu} 2$ and $\mathrm{Hal} 2$ ions in the adjacent sheets approach each other close to the sum of van der Waals radii threshold providing electrostatic attraction that holds the sheets together.

The $\mathrm{O} 3$ and $\mathrm{C} 5$ atoms in the neighboring dapa moieties approach each other to a distance shorter than the sum of respective van der Waals radii, which could be interpreted as a consequence of dipoledipole interaction or packing effects.

Compounds I and II demonstrate the joint action of copper(I) halide catenation and crosslinkage by organic molecules resulting into formation of polymers of higher dimension than copper(I) halide chains on their own. Their case illustrates how increase in hardness of potential $\sigma$-donating atoms causes a transition from one coordination mode to the other in ligands with similar geometry of copper(I) binding site.

\section{Conclusions}

Two copper(I) $\pi$-complexes, $\left[\mathrm{Cu}_{2}(\mathrm{dau}) \mathrm{Cl}_{1.58} \mathrm{Br}_{0.42}\right]$ (I) and $\left[\mathrm{Cu}_{2}\right.$ (dapa) $\left.\mathrm{Cl}_{1.74} \mathrm{Br}_{0.26}\right]$ (II), (where dau and dapa are 1,3-diallylurea and 1,3-diallylparabanate, respectively) were prepared and characterized for the first time in this work. Both structures contain two crystallographically independent copper(I) ions with one half in trigonal planar coordination environment and the other half in trigonal pyramidal one. Both compounds are built of parallel copper halide polymeric chains of one type in I and two types in II, cross-linked by organic ligand molecules to produce $3 \mathrm{D}$-polymer bulk in I and 2D-layered structure in II. The structure of II is noteworthy due to the combination of two different chain types that have been previously observed only separately in copper(I) halide coordination compounds. 


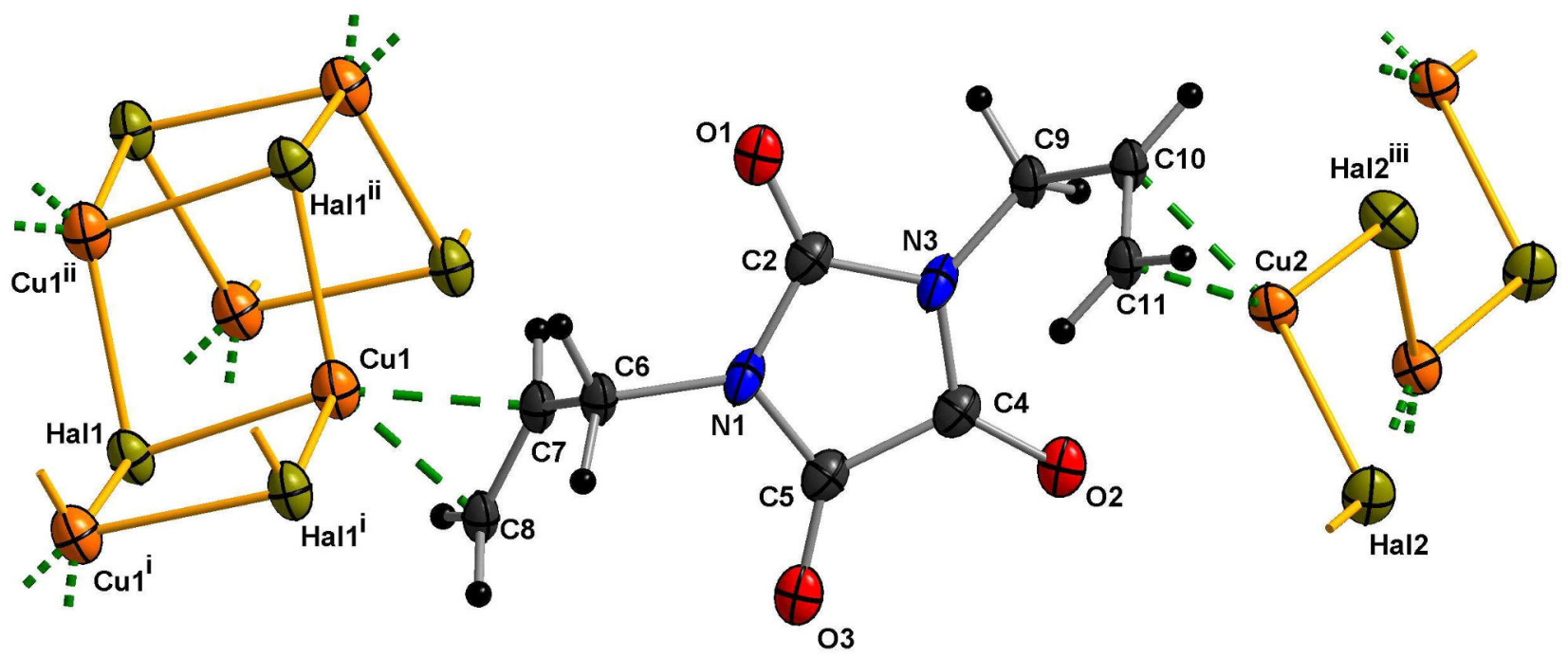

Fig. 4. Numbering scheme in structure of compound II. Thermal ellipsoids are shown at $50 \%$ probability level. Symmetry codes: (i) $-\mathrm{x}+1 / 2, \mathrm{y},-\mathrm{z}+1$; (ii) $-\mathrm{x}+1,-\mathrm{y},-\mathrm{z}+1$; (iii) $\mathrm{x}+1 / 2,-\mathrm{y}+1, \mathrm{z}$
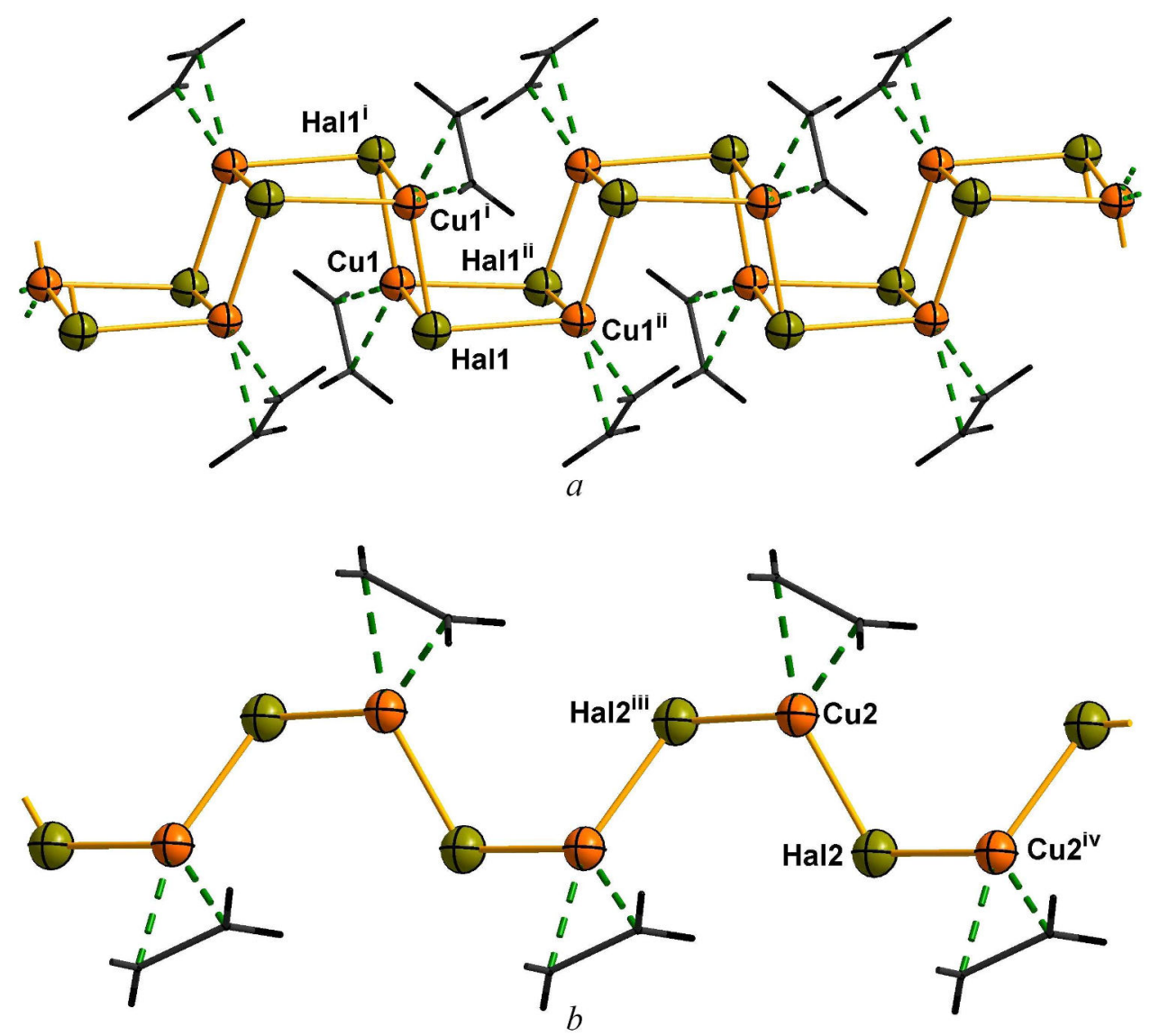

Fig. 5. Two types of copper(I) halide chains in structure of compound II. Symmetry codes: (i) $-\mathrm{x}+1 / 2, \mathrm{y},-\mathrm{z}+1$; (ii) $-\mathrm{x}+1,-\mathrm{y},-\mathrm{z}+1$; (iii) $\mathrm{x}+1 / 2,-\mathrm{y}+1$, $\mathrm{z}$; (iv) $\mathrm{x}-1 / 2,-\mathrm{y}+1, \mathrm{z}$ 


\section{REFERENCES}

1. Peng R., Li M., Li D. Copper(I) halides: a versatile family in coordination chemistry and crystal engineering // Coord. Chem. Rev. - 2010. - Vol.254. - P.1-18.

2. Goreshnik E.A., Schollmeyer D., Myskiv M.G. Syntheses and crystal structures of two non-isostructural copper(I) chloride and bromide $\pi$-complexes with (2-allylthio)benzimidazole of 1:1 composition // Z. Anorg. Allg. Chem. - 2002. - Vol.628. P.2118-2122.

3. Goreshnik E.A., Mys'kiv M.G. 2-Imino-3-allylbenzothiazole as a $\pi$-ligand: synthesis and crystal structure of $\left[(\mathrm{CuCl}) \mathrm{C}_{10} \mathrm{H}_{10} \mathrm{SN}_{2}\right], \quad\left[\mathrm{C}_{10} \mathrm{H}_{11} \mathrm{SN}_{2}^{+}\right]_{2}\left[\mathrm{Cu}_{2} \mathrm{Cl}_{4}\right]^{2-}, \quad$ and $\left[\mathrm{C}_{10} \mathrm{H}_{11} \mathrm{SN}_{2}{ }^{+}\right]_{2}\left[\mathrm{Cu}_{2} \mathrm{Cl}_{4}\right]^{2-} \pi$-compounds // Z. Anorg. Allg. Chem. - 2007. - Vol.633. - P.1723-1726.

4. Goreshnik E.A., Mys'kiv M.G. Structural dynamics of isomorphic substitution in $\mathrm{N}, \mathrm{N}$ '-diallylbenzimidazolium copper halide $\pi$-complexes $\left[\mathrm{C}_{7} \mathrm{H}_{5} \mathrm{~N}_{2}\left(\mathrm{C}_{3} \mathrm{H}_{5}\right)_{2}\right]^{+}\left[\mathrm{Cu}_{2} \mathrm{Cl}_{3-\mathrm{x}} \mathrm{Br}_{\mathrm{x}}\right]^{-}(\mathrm{x}=0,1.60$, 2.33, 3) // J. Struct. Chem. - 2004. - Vol.45. - P.276-280.

5. Copper $(I) \pi$-complexes with allyl derivatives of heterocyclic compounds: structural survey of their crystal engineering / Slyvka Y., Goreshnik E., Pavlyuk O., Mys'kiv M. // Centr. Eur. J. Chem. - 2013. - Vol.11. - P.1875-1901.

6. Kelemu S.W., Steel P.J. Allylureas: potent argentophiles with a marked propensity to form one-dimensional coordination polymers // Cryst. Growth Des. - 2014. - Vol.14. - P.12451250 .

7. Cover net systems for encapsulation films comprising urea compounds / Ulbricht D., Hein M., Kleff F., Schauhoff F., Ohlemacher J. - Patent US. - No. 9587061 B2. - 2017.

8. Davis T.L., Underwood Jr. H.W. The urea dearrangement // J. Am. Chem. Soc. - 1922. - Vol.44. - P.2595-2604.

9. Murray J.I. Parabanic acid // Org. Synth. -1957. Vol.37. - P.71-73.

10. Yang L. Powell D.R., Houser R.P. Structural variation in copper(I) complexes with pyridylmethylamide ligands: structural analysis with a new four-coordinate geometry index, $\tau_{4} / /$ Dalton Trans. - 2007. - P.955-964.

11. Syntheses and crystal structures of the copper(I) complexes with quinoline-based monothioether ligands / R.-F Song., Y.-B. Xie, J.-R. Li, X.-H. Bu // CrystEngComm. 2005. - Vol.7. - P.249-254.

12. Porous copper(I) complexes of 2,11-dithia[3.3]paracyclophane: desorption and adsorption of guest molecules / Liu S.Q., Konaka H., Kuroda-Sowa T., Suenaga Y., Ito H.,
Ning G.L., Munakata M. // Inorg. Chim. Acta. - 2004. - Vol.357. - P.3621-3631.

13. Sheldrick G.M. SHELXT - Integrated space-group and crystal-structure determination // Acta Cryst. A - 2015. Vol.A71. - P.3-8.

14. Sheldrick G.M. Crystal structure refinement with SHELXL // Acta Cryst. C - 2015. - Vol.71. - P.3-8.

15. OLEX2 a complete structure solution, resnement and analysis program / Dolomanov O.V., Bourhis L.J., Gildea R.J., Howard J.A.K., Puschmann H. // J. App. Cryst. - 2009. - Vol.42. - P.339-341.

Received 31.01.2019

\section{ПЕРШІ $\pi$-КОМПЛЕКСИ ГАЛОГЕНІДІВ КУПРУМУ(І) 3 АЛІЛЬНИМИ ПОХІДНИМИ СЕЧОВИНИ І ПАРАБАНОВОЇ КИСЛОТИ}

\section{А.І. Янчак, Ю.І. Сливка, В.В. Кінжибало, Т.Ю. Беднарчук,} М.Г. Миськів

Шляхом електрохімічного синтезу зі змінним струмом у метанольному розчині реагентів на мідних електродах було одержсано два нових $\pi$-комплекси міді(I): $\left[\mathrm{Cu}_{2}(\mathrm{dau}) \mathrm{Cl}_{1.58} \mathrm{Br}_{0.42}\right]$ (I) i $\left[\mathrm{Cu}_{2}(\right.$ dapa $\left.) \mathrm{Cl}_{1.74} \mathrm{Br}_{0.26}\right]$ (II) (dau - 1,3-діалілсечовина, dара - 1,3-діалілпарабанат)- виходячи з відповідних діаліл-похідних i галогенідів купруму(II). Сполука I кристалізується в орторомбічній сингонії, просторова група $P 2_{1} 2_{l} 2_{l}$ : $a=8.047(3) A$, $b=8.154(3) \AA A, c=16.533(5) \AA A, V=1085.8(76) A^{3}, Z=4$. Сполука $I$ кристалізується в моноклінній сингонії, просторова група I2/ $a: a=6.420(3) \AA, b=8.088(3) \AA, c=49.020(9) \AA, \beta=90.92(3)^{\circ}$, $V=2545.03(16) A^{3}, Z=8$. Обидві структури містять по два кристалографічно незалежних атоми Купруму, з яких одна половина знаходиться в тригональному координаційному оточенні, тоді як інша знаходиться у тригонально-пірамідальному оточенні. Обидві сполуки побудовані із паралельних ланцюгів галогенідів купруму (I) одного типу в I й двох типів у II, сполучених між собою молекулами органічних лігандів, що призводить до тривимірного каркаса в I і двовимірних шарів у II. В I 1,3-диалілсечовина одночасно $\pi$ - $i \sigma$-зв'язана із ланцюгами галогенідів купруму(I) (за рахунок двох алільних груп і карбонільного атома Оксигену), тоді як в II 1,3-диалілпарабанат виключно $\pi$-донорний ліганд. Структура сполуки II варта уваги через сумісну присутність двох різних типів полімерних ланиюгів галогенідів купруму (I), які до цього спостерігались в кристалічних структурах лише окремо.

Ключові слова: галогеніди купруму(I), $\pi$-комплекс, діалілсечовина, діалілпарабанат, кристалічна структура. 


\section{THE FIRST COPPER(I) HALIDE $\pi$-COMPLEXES WITH ALLYL DERIVATIVES OF UREA AND PARABANIC ACID}

A.I. Yanchak ${ }^{a}$, Yu.I. Slyvka ${ }^{a}$, V.V. Kinzhybalo ${ }^{b}$,

T.J. Bednarchuk ${ }^{b}$, M.G. Mys'kiv ${ }^{a,}$ *

a Ivan Franko National University of Lviv, Lviv, Ukraine

${ }^{b}$ Institute of Low Temperature and Structure Research,

Wroclaw, Poland

*e-mail: marian.myskiv@Inu.edu.ua

By means of alternating current electrochemical synthesis with wire copper electrodes in methanolic solutions of corresponding ligands and copper(II) halide salts, two novel copper(I) $\pi$-complexes $\left[\mathrm{Cu}_{2}\right.$ (dau) $\left.\mathrm{Cl}_{1.58} \mathrm{Br}_{0.42}\right]$ (I) and $\left[\mathrm{Cu}_{2}\right.$ (dapa) $\left.\mathrm{Cl}_{1.74} \mathrm{Br}_{0.26}\right]$ (II) (where dau and dapa are 1,3-diallylurea and 1,3-diallylparabanate, respectively) were prepared in well-shaped crystalline form and studied with $X$-ray diffraction method. Compound I crystallizes in orthorhombic crystal system, space group $P 2_{1} 2_{1} 2_{1}: a=8.047(3) A, b=8.154(3) A$, $c=16.533(5) A, V=1085.8(76) A^{3}, Z=4$. Compound II crystalizes in monoclinic crystal system, space group I2/a: $a=6.420(3) A$, $b=8.088(3) \AA, c=49.020(9) \AA, \beta=90.92(3)^{\circ}, V=2545.03(16) A^{3}$, $Z=8$. Both structures contain two crystallographically independent copper(I) ions with one half in trigonal planar coordination environment and the other half in trigonal pyramidal one. Both compounds are built of parallel copper halide polymeric chains of one type in I and two types in II, cross-linked by organic ligand molecules to produce 3D-polymer bulk in I and 2D-layered structure in II. In compound I, 1,3-diallylurea is both $\pi$-and $\sigma$-bonded to copper(I) halide chains (by means of two allylic $C=C$ bonds and carbonyl $O$ atom), whereas 1,3-diallylparabanate is a solely $\pi$-donor ligand in compound II. The structure of II is noteworthy due to the combination of two different chain types that have been previously observed only separately in copper(I) halide coordination compounds.

Keywords: copper(I) halides; $\pi$-complex; diallylurea; diallylparabanate; crystal structure.

\section{REFERENCES}

1. Peng R., Li M., Li D. Copper(I) halides: a versatile family in coordination chemistry and crystal engineering. Coordination Chemistry Reviews, 2010, vol. 254, pp. 1-18.

2. Goreshnik E.A., Schollmeyer D., Myskiv M.G. Syntheses and crystal structures of two non-isostructural copper(I) chloride and bromide $\pi$-complexes with (2-allylthio)benzimidazole of 1:1 composition. Zeitschrift für Anorganische und Allgemeine Chemie, 2002, vol. 628, pp. 2118-2122.

3. Goreshnik E.A., Mys'kiv M.G. 2-Imino-3-allylbenzothiazole as a $\pi$-ligand: synthesis and crystal structure of $\left[(\mathrm{CuCl}) \mathrm{C}_{10} \mathrm{H}_{10} \mathrm{SN}_{2}\right],\left[\mathrm{C}_{10} \mathrm{H}_{11} \mathrm{SN}_{2}{ }^{+}\right]_{2}\left[\mathrm{Cu}_{2} \mathrm{Cl}_{4}\right]^{2-}$, and $\left[\mathrm{C}_{10} \mathrm{H}_{11} \mathrm{SN}_{2}{ }^{+}\right]_{2}\left[\left.\mathrm{Cu}_{2} \mathrm{Cl}_{4}\right|^{2-}\right.$ $\pi$-compounds. Zeitschrift für Anorganische und Allgemeine Chemie, 2007, vol. 633, pp. 1723-1726.
4. Goreshnik E.A., Mys'kiv M.G. Structural dynamics of isomorphic substitution in $\mathrm{N}, \mathrm{N}^{\prime}$-diallylbenzimidazolium copper halide $\pi$-complexes $\left[\mathrm{C}_{7} \mathrm{H}_{5} \mathrm{~N}_{2}\left(\mathrm{C}_{3} \mathrm{H}_{5}\right)_{2}\right]^{+}\left[\mathrm{Cu}_{2} \mathrm{Cl}_{3-\mathrm{x}} \mathrm{Br}_{\mathrm{x}}\right]^{-}(\mathrm{x}=0,1.60$, 2.33, 3). Journal of Structural Chemistry, 2004, vol. 45, pp. 276280 .

5. Slyvka Y., Goreshnik E., Pavlyuk O., Mys'kiv M. Copper(I) $\pi$-complexes with allyl derivatives of heterocyclic compounds: structural survey of their crystal engineering. Central European Journal of Chemistry, 2013, vol. 11, pp. 1875-1901.

6. Kelemu S.W., Steel P.J. Allylureas: potent argentophiles with a marked propensity to form one-dimensional coordination polymers. Crystal Growth \& Design, 2014, vol. 14, pp. 1245-1250.

7. Ulbricht D., Hein M., Kleff F., Schauhoff F., Ohlemacher J., Cover net systems for encapsulation films comprising urea compounds. Patent US, no. 9587061 B2, 2017.

8. Davis T.L., Underwood Jr. H.W. The urea dearrangement. Journal of the American Chemical Society, 1922, vol. 44, pp. 2595-2604.

9. Murray J.I. Parabanic acid. Organic Syntheses, 1957, vol. 37, pp. 71-73.

10. Yang L. Powell D.R., Houser R.P. Structural variation in copper(I) complexes with pyridylmethylamide ligands: structural analysis with a new four-coordinate geometry index, $\tau_{4}$. Dalton Transactions, 2007, pp. 955-964.

11. Song R.-F., Xie Y.-B., Li J.-R., Bu X.-H. Syntheses and crystal structures of the copper(I) complexes with quinolinebased monothioether ligands. CrystEngComm, 2005, vol. 7, pp. 249-254.

12. Liu S.Q., Konaka H., Kuroda-Sowa T., Suenaga Y., Ito H., Ning G.L., Munakata M. Porous copper(I) complexes of 2,11-dithia[3.3]paracyclophane: desorption and adsorption of guest molecules. Inorganica Chimica Acta, 2004, vol. 357, pp. 36213631

13. Sheldrick G.M. SHELXT - Integrated space-group and crystal-structure determination. Acta Crystallographica, Section A: Foundations of Crystallography, 2015, vol. A71, pp. 3-8.

14. Sheldrick G.M. Crystal structure refinement with SHELXL. Acta Crystallographica, Section C: Crystal Structure Communications, 2015, vol. C71, pp. 3-8.

15. Dolomanov O.V., Bourhis L.J., Gildea R.J., Howard J.A.K., Puschmann H. OLEX2: a complete structure solution, resnement and analysis program. Journal of Applied Crystallography, 2009, vol. 42, pp. 339-341. 